\title{
KANDUNGAN ZAT GIZI DAN TINGKAT KESUKAAN ROTI MANIS SUBSTITUSI TEPUNG SPIRULINA SEBAGAI ALTERNATIF MAKANAN TAMBAHAN ANAK GIZI KURANG
}

\author{
Eveline Sugiharto, Fitriyono Ayustaningwarno*) \\ Program Studi Ilmu Gizi Fakultas Kedokteran Universitas Diponegoro \\ Jl.Dr.Sutomo No.18, Semarang, Telp (024) 8453708, Email : gizifk@undip.ac.id
}

\begin{abstract}
Background :Undernutrition, both macronutrient (protein) and micronutrient (vitamin $A$ and iron) in children under five resulting in impaired growth, intellectual impairment, degradation of body resistance so children under five will be more vulnerable to infection and increase of mortality rate. Supplementary food with high protein, vitamin A and iron needs to be given to prevent malnutrition problems. Spirulina is high in protein, $\beta$-carotene, and iron. Sweet bread substitutedwith spirulina powder was expected to be an alternative food with high protein, vitamin A and iron. Objective : Analyze the nutrition content and preference level of sweet bread substituted with spirulina powder.

Method: The completely randomized single factor design with 3 levels spirulina powder substitution with wheat flour, which were $10 \%, 15 \%$ and $20 \%$. Nutritient-content's data was analyzed by One Way ANOVA test continued with Tukey test. Preference level test was done by hedonic test in 30 consumer panelists and analyzed by Friedman test continued with Wilcoxon test.

Result :The nutrition content of sweet bread with 10\%, 15\%, and 20\% spirulina powder substitutionper 100 grams are 9,13;10,66;12,90g protein, 2,07;2,28;2,67g fat, 46,28;44,70;42,06g carbohydrate, 1,55;1,68;2,61mg $\beta$-carotene, and 5,71;7,45;9,56mg iron. The highest preference level for colour, flavor, texture, and aromawasfound in sweet bread with $10 \%$ spirulina powder substitution.

Conclusion :Substitution of spirulina powder increases the nutrient content of sweet bread (except carbohydrates) and decrease the preference level by the panelists.

Keyword : sweet bread; spirulina powder; nutrition conten; preference level
\end{abstract}

\begin{abstract}
ABSTRAK
Latar Belakang : Kekurangan zat gizi, baik zat gizi makro (protein) maupun mikro (vitamin A dan zat besi) pada balita akan mengakibatkan gangguan pertumbuhan, gangguan intelektual, penurunan daya tahan tubuh sehingga balita lebih rentan terhadap infeksi dan peningkatan angka kematian. Pemberian Makanan Tambahan tinggi protein, vitamin A dan zat besi perlu diberikan untuk mencegah masalah kekurangan zat gizi. Spirulina merupakan bahan makanan tinggi protein, $\beta$-karoten dan zat besi. Roti manis yang disubstitusi dengan tepung spirulina diharapkan dapat menjadi alternatif makanan tambahan tinggi protein, vitamin A dan zat besi.

Tujuan : Menganalisis kandungan zat gizi dan tingkat kesukaan roti manis substitusi tepung spirulina.

Metode :Merupakan penelitian eksperimental rancangan acak lengkap satu faktor yaitu substitusi tepung terigu dengan tepung spirulina (10\%, 15\%, dan 20\%). Perbedaan kandungan zat gizi dianalisis menggunakan uji One Way ANOVA dengan uji lanjut Tukey. Uji tingkat kesukaan dilakukan dengan uji hedonik pada 30 orang panelis konsumen dan dianalisis menggunakan uji Friedman dengan uji lanjut Wilcoxon.

Hasil :Kandungan zat gizi per 100 gram roti manis substitusi tepung spirulina $10 \%, 15 \%$ dan $20 \%$ secara berturutturut adalah 9,13;10,66;12,90g protein, 2,07;2,28;2,67g lemak, 46,28;44,70;42,06g karbohidrat, 1,55;1,68;2,61mg $\beta$-karoten, dan 5,71,7,45;9,56mg zat besi. Hasil uji tingkat kesukaan terhadap warna, rasa, tekstur, dan aroma tertinggi diperoleh roti manis dengan substitusi tepung spirulina $10 \%$.

Kesimpulan :Substitusi tepung spirulina meningkatkan kandungan zat gizi roti manis (kecuali karbohidrat) dan menurunkan tingkat kesukaan oleh panelis.

Kata kunci : roti manis; tepung spirulina; kandungan zat gizi; tingkat kesukaan

\section{PENDAHULUAN}

Masalah gizi kurang merupakan masalah kesehatan masyarakat yang sering ditemukan pada balita, khususnya usia enam bulan sampai dua tahun. ${ }^{1}$ Laporan evaluasi pencapaian MDGs di Indonesia menyatakan prevalensi balita dengan status gizi kurang (z-skor $\mathrm{BB} / \mathrm{U} \geq-3$ SD sampai dengan <-2 SD) pada tahun 2007 dan 2010 sebesar $13,0 \%$ dan meningkat menjadi $13,9 \%$ pada tahun

buruk meningkat dari $4,9 \%$ pada tahun 2010 menjadi $5,7 \%$ pada tahun $20133^{2,3}$

Masalahkekurangan gizi meliputi masalah kekurangan zat gizi makro dan zat gizi mikro. Kekurangan zat gizi, baik zat gizi makro maupun mikro akan mengakibatkan gangguan pertumbuhan, gangguan intelektual, penurunan daya tahan tubuh sehingga balita lebih rentan terhadap infeksi dan peningkatan angka kematian. ${ }^{4}$
\end{abstract} 2013, sedangkan prevalensi balita dengan status gizi 
Salah satu zat gizi makro yang menjadi kebutuhan dasar bagi anak balita untuk pertumbuhan dan perkembangan sel adalah protein. Apabila asupan protein pada balita kurang, maka akan mengakibatkan pertumbuhan dan perkembangan anak terganggu, dalam jangka panjang mengakibatkan stunting pada anak. ${ }^{5}$

Kekurangan zat gizi mikro yaitu kekurangan vitamin A (KVA) masih menjadi perhatian dalam upaya perbaikan gizi masyarakat. Meskipun masalah KVA secara klinis sudah teratasi, masih terdapat KVA subklinis yang masih ada pada kelompok balita. KVA subklinis merupakan KVA yang belum menampakkan gejala nyata, yang hanya dapat diketahui dengan memeriksa serum retinol dalam darah di laboratorium. ${ }^{6,7}$

Selain KVA, anemia gizi besi juga merupakan masalah kekurangan gizi mikro yang masih sering ditemui. Berdasarkan hasil Riskesdas 2013, proporsi anemia pada balita umur 12-59 bulan secara nasional cukup tinggi, yaitu sebesar $28,1 \%$. Anak dengan anemia biasanya memiliki gejala lelah, lesu, lemah, letih, lalai (5L) sehingga mengakibatkan kurangnya konsentrasi anak, mempengaruhi status intelektual, gangguan pertumbuhan, dan mempengaruhi kekuatan fisik. ${ }^{8,9,10}$

Pencegahan kekurangan gizi dapat dilakukan dengan melakukan suplementasi, perubahan diet, dan fortifikasi. ${ }^{4}$ Selain itu, Pemberian Makanan Tambahan (PMT) pada balita gizi kurang juga menjadi salah satu upaya pencegahan dan perbaikan kekurangan gizi di Indonesia. ${ }^{11}$ PMT akan lebih baik bila berasal dari campuran pangan lokal dengan fortifikasi atau suplementasi agar dapat memenuhi kecukupan gizi bagi balita gizi kurang. ${ }^{12}$ WHO telah menetapkan anjuran komposisi makanan tambahan untuk digunakan dalam manajemen malnutrisi akut tingkat sedang (gizi kurang) pada balita. ${ }^{13}$

Spirulina merupakan mikroalga yang termasuk dalam cyanobacteria atau bakteri dengan pigmen hijau-biru yang mengandung klorofil dan dapat bertindak sebagai organisme yang melakukan fotosintesis. Spirulina merupakan salah satu bahan makanan yang tinggi protein, vitamin dan mineral. Kadar protein pada spirulina dalam berat kering bervariasi antara $50 \%$ sampai $70 \% .{ }^{14}$ Kadar protein pada spirulina basah di Jepara diketahui sebesar $65,37 \%$ dari berat kering. ${ }^{15}$ Kadar lemak pada spirulina berkisar antara $4-7 \%$ dari berat kering. ${ }^{16,17,18}$ Kadar karbohidrat pada spirulina sebesar $15-25 \%$ dari berat kering.Beta-karoten $(\beta$ karoten) merupakan karotenoid terbanyak dalam spirulina (sekitar 80\%).Kadar zat besi dalam spirulina kering adalah $15-25 \mathrm{mg} / 100 \mathrm{~g}$ spirulina kering. ${ }^{16,18}$

Spirulina telah digunakan untuk memperbaiki status gizi kurang pada anak pada penelitian tahun 2002, dimana spirulina dicampurkan dengan misola (campuran millet, soja, peanut),kemudian diberikan kepada balita status gizi kurang. Pemberian spirulina dan misoladapat menjadi suplemen makanan yang baik untuk memperbaiki penurunan berat badan pada balita dengan status gizi kurang maupun buruk. ${ }^{19}$

Anak balita menyukai makanan yang lebih mudah dikunyah misalnya roti dan biskuit dibandingkan daging dan makanan sumber protein. ${ }^{5}$ Spirulina memiliki sifat fungsional protein berupa daya ikat terhadap air yang sesuai untuk produk olahan daging (sosis, bakso) dan roti. ${ }^{15} \mathrm{Pada}$ penelitian ini, dilakukan substitusi tepung spirulina pada roti manis. Substitusi tepung spirulina pada roti manis diharapkan dapat meningkatkan kandungan zat gizi, khususnya protein, $\beta$-karoten dan zat besi pada roti manis. Berdasarkan latar belakang tersebut maka dilakukan penelitian mengenai kandungan zat gizi dan tingkat kesukaan roti manis substitusi tepung spirulina sebagai alternatif makanan tambahan anak gizi kurang.

\section{METODE}

Penelitian yang dilakukan ditinjau dari segi keilmuan termasuk dalam bidang food production. Penelitian dilaksanakan pada bulan Mei hingga Juni di Laboratorium Ilmu Teknologi Pangan Universitas Muhammadiyah Semarang untuk melakukan uji kandungan zat gizi dan uji tingkat kesukaan dilaksanakan pada 30 panelis konsumen yaitu ibu balita di Posyandu Sakura RW 13 Kelurahan Tegalsari Semarang.

Sebelum penelitian utama, dilakukan penelitian pendahuluan bertujuan untuk menemukan formulasi terbaik untuk pembuatan roti manis substitusi tepung spirulina berdasarkan aroma dan tekstur yang dihasilkan. Tahap yang dilakukan dalam penelitian pendahuluan adalah menentukan tingkat substitusi maksimum tepung terigu dengan tepung spirulina berdasarkan pada aroma dan rasa. Substitusi maksimum tepung spirulina pada roti manis adalah $20 \%$, sehingga ditentukan tiga formulasi yaitu 10\% (P1), 15\% (P2) dan 20\% (P3).

Penelitian utama dengan rancangan acak lengkap satu faktor, yaitu variasi konsentrasi substitusi tepung spirulina yang digunakan pada proses pembuatan roti manis $(10 \%, 15 \%$, dan $20 \%)$. Bahan-bahan yang digunakan dalam pembuatan roti manis antara tepung terigu protein sedang, tepung 
terigu protein tinggi, gula, ragi instan, bread improver, mentega, susu bubuk, garam, telur, dan tepung spirulina "Neoalgae Spirulina" yang diproduksi CV. Neoalgae Technology. Formulasi substitusi tepung spirulina terhadap tepung terigu disajikan dalam Tabel 1., untuk jumlah penggunaan bahan lainnya sesuai dengan standar resep pada Lampiran 2.

Tabel 1. Formulasi Substitusi Tepung Spirulina terhadap Tepung Terigu

\begin{tabular}{ccccc}
\hline Jenis Bahan & \multicolumn{3}{c}{ Formulasi } \\
\cline { 2 - 5 } & & P1 (10\%) & P2 (15\%) & P3 (20\%) \\
\hline Terigu Protein Sedang & $\%$ & 10 & 5 & 0 \\
Terigu Protein Tinggi & $\%$ & 80 & 80 & 80 \\
Tepung Spirulina & $\%$ & 10 & 15 & 20 \\
\hline
\end{tabular}

Alat yang digunakan dalam pembuatan roti manis antara lain timbangan digital, baskom, mixer, dough mixer, prover, loyang, spatula, oven. Pembuatan roti manis dilakukan dengan menimbang semua bahan, mencampurkan bahan biang (tepung terigu, air, ragi, gula), fermentasi bahan biang, mencampurkan seluruh bahan dengan dough mixer, pemotongan dan pembulatan roti manis, kemudian dilakukan fermentasi akhir dalam prover, dan terakhir dipanggang menggunakan oven pada suhu $185^{\circ} \mathrm{C}$ selama 15 menit.

Roti manis substitusi tepung spirulina selanjutnya dianalisis kadarprotein, lemak, karbohidrat, $\beta$-karoten, dan zat besi, serta tingkat kesukaan. Uji kandungan zat gizi dilakukan 3 kali pengulangan secara duplo.Analisis kadar protein total dengan metode mikro-Kjehdahl, kadar lemak total dilakukan dengan metode soxhletasi, kadar karbohidrat dengan perhitungan dalam persentase, kadar $\beta$-karoten dengan spektrofotometer, dan zat besi dengan Atomic Absorbent Spectrofotometri (AAS). ${ }^{20,21}$

Ujitingkat kesukaanmenggunakan 5 skala, yaitu 1=Sangat Tidak Suka, 2=Tidak Suka, $3=$ Netral, 4=Suka, 5=Sangat Suka, dilakukan pada 30 orang panelis konsumen yang merupakan ibu balita di Posyandu Sakura RW 13 Kelurahan Tegalsari Semarang. Uji tingkat kesukaan menggunakan parameter warna, aroma, tekstur, dan rasa. $^{22}$

Data kandungan zat gizi yang terkumpul selanjutnya dianalisis menggunakan SPSSfor Windows. Analisis data kandungan zat gizi dengan cara menguji normalitas data dan diketahui bahwa data berdistribusi normal, selanjutnya dianalisis menggunakan uji One Way ANOVA CI 95\% dengan uji lanjut Tukey. Sedangkan data tingkat kesukaan berdistribusi tidak normal, sehingga dianalisis menggunakan uji Friedman CI 95\% dengan uji lanjut Wilcoxon. Penentuan roti manis terbaik dilakukan untuk mengetahui roti manis yang dapat digunakan untuk pemberian makanan tambahan pada balita gizi kurang. Roti manis terbaik ditentukan berdasarkan pemenuhan kandungan zat gizi dibandingkan dengan anjuran komposisi makanan tambahan berdasarkan WHO dan tingkat kesukaan dari hasil uji tingkat kesukaan.

\section{HASIL}

Kadar Protein, Lemak, Karbohidrat, $\beta$-karoten, dan Zat Besi Roti Manis Substitusi Tepung Spirulina

Hasil analisis kadar protein, lemak, karbohidrat, $\beta$-karoten, dan zat besi roti manis substitusi tepung spirulina disajikan pada Tabel 2.

Tabel 2. Hasil Analisis Kadar Protein, Lemak, Karbohidrat, $\beta$-karoten, dan Zat Besi Roti Manis Substitusi Tepung Spirulina

\begin{tabular}{lccccc}
\hline Perlakuan & \multicolumn{5}{c}{ Rerata Kandungan Zat Gizi } \\
\cline { 2 - 6 } & $\begin{array}{c}\text { Protein } \\
(\%)\end{array}$ & $\begin{array}{c}\text { Lemak } \\
(\%)\end{array}$ & $\begin{array}{c}\text { Karbohidrat } \\
(\%)\end{array}$ & $\begin{array}{c}\beta \text {-karoten } \\
(\mathrm{mg} / 100 \mathrm{~g})\end{array}$ & $\begin{array}{c}\text { Zat Besi } \\
(\mathrm{mg} / 100 \mathrm{~g})\end{array}$ \\
\hline P1 $(10 \%)$ & $9.13 \pm 0.22^{\mathrm{a}}$ & $2.07 \pm 0.04^{\mathrm{a}}$ & $46.28 \pm 0.37^{\mathrm{a}}$ & $1.55 \pm 0.04^{\mathrm{a}}$ & $5.71 \pm 0.24^{\mathrm{a}}$ \\
P2 $(15 \%)$ & $10.66 \pm 0.27^{\mathrm{b}}$ & $2.28 \pm 0.10^{\mathrm{b}}$ & $44.70 \pm 0.36^{\mathrm{b}}$ & $1.68 \pm 0.16^{\mathrm{b}}$ & $7.45 \pm 0.48^{\mathrm{b}}$ \\
P3 $(20 \%)$ & $12.90 \pm 0.28^{\mathrm{c}}$ & $2.67 \pm 0.14^{\mathrm{c}}$ & $42.06 \pm 0.38^{\mathrm{c}}$ & $2.61 \pm 0.10^{\mathrm{c}}$ & $9.56 \pm 0.36^{\mathrm{c}}$ \\
\hline & $\mathbf{p = 0 . 0 0 0}$ & $\mathbf{p = 0 . 0 0 0}$ & $\mathbf{p = 0 . 0 0 0 *}$ & $\mathbf{p = 0 . 0 0 0 *}$ & $\mathbf{p = 0 . 0 0 0}$ \\
\hline
\end{tabular}

Keterangan: Angka yang diikuti dengan huruf superscript berbeda (a,b,c) menunjukkan beda nyata pada kolom yang sama.

Berdasarkan Tabel 2, roti manis P3 (substitusi tepung spirulina sebesar 20\%) memiliki kadar protein, lemak, $\beta$-karoten, dan zat besi tertinggi dibandingkan dengan perlakuan lainnya.
Sedangkan kadar karbohidrat tertinggi terdapat pada P1 yaitu substitusi sebesar $10 \%$.

Berdasarkan hasil analisis disimpulkan bahwa terdapat pengaruh substitusi tepung spirulina 
pada kandungan gizi roti manis. Hasil analisis tersebut menyatakan bahwa semakin banyak substitusi tepung spirulina pada roti manis maka kadar protein, lemak, $\beta$-karoten, dan zat besi semakin tinggi, sedangkan kadar karbohidrat semakin rendah.

\section{Tingkat Kesukaan Roti Manis Substitusi Tepung Spirulina}

Hasil analisis tingkat kesukaan roti manis substitusi tepung spirulina disajikan pada Tabel 3.

Tabel 3. Hasil Analisis Tingkat Penerimaan Roti Manis Substitusi Tepung Spirulina

\begin{tabular}{ccccccccc}
\hline \multirow{2}{*}{ Perlakuan } & \multicolumn{2}{c}{ Warna } & \multicolumn{2}{c}{ Rasa } & \multicolumn{2}{c}{ Tekstur } & \multicolumn{2}{c}{ Aroma } \\
\cline { 2 - 9 } & Rerata & Ket & Rerata & Ket & Rerata & Ket & Rerata & Ket \\
\hline P1 $(10 \%)$ & $2.70 \pm 0.95$ & Netral & $3.07 \pm 0.83^{\mathrm{a}}$ & Netral & $3.20 \pm 0.66$ & Netral & $3.27 \pm 0.69^{\mathrm{a}}$ & Netral \\
\hline P2 $(15 \%)$ & $2.70 \pm 0.79$ & Netral & $2.80 \pm 0.66^{\mathrm{a}}$ & Netral & $2.90 \pm 0.61$ & Netral & $2.97 \pm 0.77^{\mathrm{b}}$ & Netral $^{\mathrm{a}}$ \\
\hline P3 $(20 \%)$ & $2.40 \pm 0.68$ & Tidak suka & $2.37 \pm 0.49^{\mathrm{b}}$ & Tidak suka & $2.93 \pm 0.64$ & Netral & $2.93 \pm 0.74^{\mathrm{b}}$ & Netral \\
\hline & $\mathbf{p = 0 . 0 9 5}$ & & $\mathbf{p = 0 . 0 0 1 *}$ & & $\mathbf{p = 0 . 1 0 9}$ & & $\mathbf{p = 0 . 0 2 2 *}$ & \\
\hline
\end{tabular}

Keterangan: Angka yang diikuti dengan huruf superscript berbeda (a,b,c) menunjukkan beda nyata pada kolom yang sama.

Tabel 3. menunjukkan bahwa tingkat kesukaan warna dan rasa roti manis yang tertinggi terdapat pada roti manis $\mathrm{P} 1$ dan $\mathrm{P} 2$ dengan tingkat penilaian netral. Sedangkan roti manis P3 mendapatkan tingkat penilaian tidak suka dari panelis. Tingkat kesukaan tekstur dan aroma pada ketiga perlakuan roti manis memiliki penilaian yang sama, yaitu netral.

Berdasarkan analisis secara statistik dapat disimpulkan bahwa terdapat pengaruh substitusi tepung spirulina terhadap tingkat kesukaan panelis akan rasa dan aroma.

\section{PEMBAHASAN}

Kandungan Zat Gizi Roti Manis Substitusi Tepung Spirulina

Salah satu cara yang diprogramkan pemerintah untuk mengatasi masalah gizi kurang pada balita adalah dengan diadakannya Pemberian Makanan Tambahan (PMT).Makanan tambahan adalah makanan bergizi sebagai tambahan selain makanan utama bagi kelompok sasaran untuk memenuhi kebutuhan gizi. PMT diberikan bagi balita umur 6-59 bulan. PMT diberikan sebagai tambahan, bukan untuk pengganti makanan utama sehari - hari. ${ }^{11}$ PMT akan lebih baik bila berasal dari campuran pangan lokal dengan fortifikasi atau suplementasi agar dapat memenuhi kecukupan gizi bagi balita gizi kurang. ${ }^{12}$

Pada penelitian ini, dilakukan substitusi tepung terigu dengan tepung spirulina untuk meningkatkan kandungan gizi roti manis sebagai alternatif makanan tambahan bagi balita gizi kurang. Berdasarkan hasil analisis, substitusi tepung spirulina berpengaruh secara nyata terhadap kandungan zat gizi pada ketiga perlakuan roti manis. Roti manis P3 dengan tingkat substitusi tepung spirulina tertinggi sebesar $20 \%$ memiliki kadar protein, lemak, $\beta$-karoten, zat besi paling tinggi dan kadar karbohidrat paling rendah.

Kadar protein, lemak dan karbohidrat digunakan untuk menghitung kalori roti manis yang dihasilkan. Kandungan energi roti manis substitusi tepung spirulina pada $\mathrm{P} 1, \mathrm{P} 2$ dan $\mathrm{P} 3$ per 100 gram secara berturut-turut yaitu 240,27; 241,96; $243,87 \mathrm{kkal}$. Kandungan energi roti manis diperoleh dengan mengkonversikan protein, lemak dan karbohidrat, dimana dihasilkan 9 kkal per gram untuk lemak, serta 4 gram untuk karbohidrat dan protein. ${ }^{23}$ Sedangkan densitas energi pada roti manis sebesar 2,40-2,44 kkal/gram. Apabila dibandingkan dengan anjuran dari WHO, densitas energi pada roti manis memenuhi anjuran yaitu tidak boleh kurang dari $0,8 \mathrm{kkal} / \mathrm{gram} .^{13}$

Tabel 4. Perbandingan Kandungan Zat Gizi Roti Manis Substitusi Tepung Spirulina dengan Anjuran Komposisi Makanan Tambahan WHO

\begin{tabular}{ccccccc}
\hline \multirow{2}{*}{ Zat Gizi } & \multicolumn{5}{c}{ Anjuran WHO } & \multicolumn{2}{c}{ Roti manis substitusi tepung spirulina } \\
\cline { 2 - 7 } & Satuan & Minimum & Maksimum & P1 & P2 & P3 \\
\hline Protein & $\mathrm{g}$ & 20 & 43 & 38.00 & 44.07 & 52.90 \\
Lemak & $\mathrm{g}$ & 25 & 65 & 8.62 & 9.42 & 10.95 \\
Zat besi & $\mathrm{mg}$ & 18 & 30 & 23.77 & 30.79 & 39.20 \\
Vitamin A (retinol) & $\mathrm{mg}$ & 2 & 3 & & & \\
$(\beta$-karoten) & $\mathrm{mg}$ & 4 & 6 & 6.45 & 6.94 & 10.70 \\
\hline
\end{tabular}


Kadar protein pada spirulina yang digunakan adalah 63-70\%. Kadar protein pada anjuran komposisi makanan tambahan berdasarkan WHO yaitu $20-43 \mathrm{~g}$ per 1000 kalori. ${ }^{13}$ Setelah dikonversikan per 1000 kalori, kadar protein pada roti manisberkisar antara 38,00-52,90. Kadar protein pada roti manis $\mathrm{P} 1(38,00 \pm 0,92 \mathrm{~g})$ memenuhi spesifikasi anjuran komposisi makanan tambahan berdasarkan WHO. Sedangkan kadar protein pada roti manis $\mathrm{P} 2(44,05 \pm 1,12 \mathrm{~g})$ dan $\mathrm{P} 3(52,90 \pm 1,15 \mathrm{~g})$ melebihi anjuran komposisi makanan tambahan berdasarkan WHO.

Kelebihan asupan protein dapat berakibat buruk pada balita dengan gizi buruk. Hal ini dikarenakan, protein yang berlebihan pada sintesis jaringan akan dipecah oleh hepar dan selanjutnya diekskresikan. Proses pemecahan protein membutuhkan energi dimana pada balita gizi kurang, energi yang didapat sangat terbatas. Selain itu, kelebihan asupan protein juga dapat menyebabkan penurunan fungsi pada ginjal. ${ }^{12}$ Pengaturan jumlah porsi dan takaran saji roti manis P2 dan P3 perlu diperhatikan untuk mencegah kelebihan asupan protein.

Kadar lemak pada roti manis spirulina apabila dibandingkan dengan anjuran komposisi makanan tambahan berdasarkan WHO masih sangat rendah. Rendahnya kadar lemak dapat disebabkan karena penggunaan mentega putih yang rendah pada standar resep $(0,1 \%)$. Selain itu, kadar lemak pada spirulina juga rendah $(7,2 \%)$. Penambahan lemak pada roti manis dapat dilakukan untuk meningkatkan kadar lemak. Lemak juga dapat mengempukkan produk, meningkatkan flavor dan memperpanjang daya simpan roti karena penambahan lemak dalam adonan akan menahan air. Lemak yang dapat ditambahkan dalam roti manis adalah minyak nabati yang sudah dihidrogenasi (margarin dan mentega putih). Hal ini dikarenakan harganya lebih murah dan teksturnya baik. ${ }^{24}$

Beta-karoten ( $\beta$-karoten) merupakan karotenoid terbanyak dalam spirulina (sekitar $80 \%$ ). Kadar $\beta$-karoten pada spirulina yang digunakan adalah $5,8 \mathrm{mg} / \mathrm{g}$. Apabila dibandingkan dengan kadar $\beta$-karoten pada tepung spirulina, terjadi penurunan kadar $\beta$-karoten sebesar 83,97\%$88,41 \%$. Penurunan ini disebabkan karena suhu dan waktu pemanggangan. Pemanggangan roti manis pada penelitian ini dilakukan pada suhu $180^{\circ} \mathrm{C}$ selama 15 menit. Semakin tinggi suhu yang digunakan dalam pemanggangan akan menghasilkan roti dengan total karotenoid yang semakin kecil akibat terjadinya pengrusakan karotenoid. Pemanggangan roti pada suhu $201^{\circ} \mathrm{C}$ selama 15 menit mengakibatkan 92\% $\beta$-karoten terdegradasi. ${ }^{25}$

Meskipun $\beta$-karoten terdegradasi, kadar $\beta$ karoten pada roti manis spirulina masih melebihi batas anjuran komposisi makanan tambahan berdasarkan WHO. Konsumsi $\beta$-karoten dalam dosis yang tinggi dapat menjadi racun.Namun apabila $\beta$-karoten diasup dari bahan nabati, maka $\beta$ karoten akan dikonversikan menjadi vitamin A dengan adanya vitamin A bebas (retinol) hanya bila dibutuhkan. ${ }^{16,18}$

Kadar zat besi pada spirulina adalah $1,5 \mathrm{mg}$ per 1g spirulina. Substitusi spirulina dalam roti manis pada ketiga perlakuan memberikan pengaruh secara bermakna terhadap peningkatan kadar zat besi. Hal ini sesuai dengan penelitian sebelumnya yaitu penambahan spirulina ( $1 \%$ dan $2 \%$ ) pada roti berbahan dasar singkong yang menghasilkan adanya peningkatan kadar abu dibandingkan dengan roti kontrol yang tidak diberi penambahan spirulina. ${ }^{26}$

Kadar zat besi pada roti manis P1 memenuhi anjuran komposisi makanan tambahan berdasarkan WHO.Sedangkan kadar zat besi pada roti manis $\mathrm{P} 2$ dan $\mathrm{P} 3$ melebihi anjuran WHO. Hal ini menunjukkan bahwa semakin besar substitusi tepung spirulina, semakin tinggi kadar zat besi. Selain itu, selain kadar zat besi pada spirulina, juga terdapat kadar zat besi pada tepung terigu yang digunakan. Pada penelitian lain diketahui bahwa tepung terigu yang digunakan mengandung 5,14$6,4 \mathrm{mg}$ per $100 \mathrm{~g}$ tepung terigu ${ }^{27}$. Kadar zat besi masih tinggi karena zat besi merupakan salah satu mineral. Mineral relatif lebih stabil pada proses pengolahan berupa panas, cahaya, dan $\mathrm{pH}$ dibanding dengan vitamin. Mineral dalam makanan dapat berkurang dalam proses pencucian maupun perebusan. Sehingga proses pemanggangan tidak terlalu berpengaruh terhadap oksidasi zat besi. ${ }^{28}$

\section{Uji Tingkat Kesukaan}

Hasil uji Friedman menunjukkan terdapat perbedaan bermakna pada ketiga perlakuan roti manis substitusi tepung spirulina terhadap aroma dan rasa. Sedangkan pada tekstur dan aroma tidak terdapat perbedaan bermakna pada ketiga perlakuan.

Warna roti manis yang dihasilkan yaitu hijau tua. Warna hijau tua berasal dari $\beta$-karoten dan klorofil pada spirulina. ${ }^{29}$ Semakin besar substitusi spirulina pada roti manis menghasilkan warna yang semakin gelap. Hasil uji kesukaan warna pada P1 adalah netral, P2 adalah netral, sedangkan P3 adalah tidak suka. Panelis yang tidak menyukai warna roti manis spirulina menyatakan bahwa warna roti terlalu gelap sehingga kurang menarik. Warna roti 
manis mempengaruhi pemilihan oleh panelis, dimana dapat disimpulkan bahwa roti manis P1 dan P2 lebih dipilih panelis daripada roti manis P3.

Uji tingkat kesukaan rasa pada roti manis $\mathrm{P} 1$ adalah netral, P2 adalah netral, dan P3 adalah tidak suka. P1 merupakan roti manis yang lebih disukai panelis pada parameter rasa (rerata $3.07 \pm 0.83$ ). Hal ini dikarenakan terdapat rasa amis yang mencolok yang merupakan karakteristik sensorik dari mikroalga seperti spirulina. Semakin banyak substitusi tepung spirulina, maka rasa amis akan semakin terasa dan mempengaruhi pemilihan rasa roti manis yang dihasilkan. ${ }^{30}$

Hasil uji kesukaan tekstur pada semua perlakuan adalah netral dengan kesukaan tertinggi pada roti manis P1. Pembuatan roti manis pada penelitian ini menggunakan tiga jenis tepung, yaitu tepung terigu protein sedang, tepung terigu protein tinggi, dan tepung spirulina. Tepung terigu yang umumnya dipakai untuk pembuatan roti adalah terigu dengan kandungan gluten atau protein gandum yang tinggi (12-13\%). Tepung terigu dengan kandungan gluten lebih banyak akan dapat menyerap air lebih banyak, sehingga dapat menghasilkan roti yang padat dan tekstur yang baik.Gluten terbentuk dari fraksi glutenin dan gliadin yang bereaksi dengan air. Gluten memiliki sifat liat dan elastis, sehingga gluten dapat menahan gas selama fermentasi atau pemanggangan roti. ${ }^{24}$

Panelis berpendapat bahwa roti manis yang dihasilkan memiliki tekstur yang keras dan kurang empuk pada permukaan roti saat dipegang, namun saat dimakan, tekstur pada bagian dalam roti terasa lembut. Penambahan lemak pada pembuatan roti manis hanya $0,1 \%$ sehingga menghasilkan tekstur permukaan roti yang agak keras. Sedangkan tekstur lembut diperoleh dari penggunaan bread improver. Pembuatan roti dengan substitusi tepung spirulinamemerlukan tambahan bread improver karena tidak tersedianya gluten dalam tepung spirulina. Bahan ini berfungsi untuk meningkatkan daya tarik menarik antara butir pati, sehingga dapat menahan gas yang terdapat dalam adonan. Penambahan bread improver akan menghasilkan adonan yang cukup mengembang dan akhirnya akan diperoleh roti dengan volume yang relatif besar, remah yang halus, dan tekstur yang lembut. ${ }^{24}$

Aroma roti manis memiliki tingkat kesukaan netral pada semua perlakuan, dengan kesukaan tertinggi pada roti manis P1. Selain rasa amis, aroma langu juga menjadi salah satu karakteristik sensorik dari mikroalga seperti spirulina. $^{30}$ Aroma ini juga mempengaruhi pemilihan aroma roti manis. Panelis berpendapat bahwa seharusnya untuk menghilangkan aroma langu, dapat dengan pemblansiran, namun pemblansiran dapat mengurangi kadar mineral yang terdapat pada spirulina. ${ }^{28}$ Alternatif lain untuk meningkatkan aroma adalah memberikan vanila.

\section{Rekomendasi Roti Manis}

Berdasarkan hasil uji kandungan gizi dan tingkat kesukaan, roti manis yang direkomendasikan adalah roti manis dengan substitusi tepung spirulina sebesar $10 \%(\mathrm{P} 1)$. Meskipun kandungan zat gizi roti manis pada P1 lebih rendah bila dibandingkan dengan perlakuan lainnya, kandungan zat gizi pada P1 memenuhi anjuran komposisi makanan tambahan bagi balita dengan gizi kurang yang ditetapkan oleh WHO. Selain itu, berdasarkan uji tingkat kesukaan, tingkat kesukaan roti manis tertinggi pada roti manis P1 dengan penilaian kategori netral dan terdapat perbedaan yang bermakna pada parameter rasa dan aroma.

\section{SIMPULAN}

Semakin tinggisubstitusi tepung spirulina pada pembuatan roti manis, kandungan zat gizi roti manis semakin meningkat (kecuali pada karbohidrat), sedangkan tingkat kesukaan semakin menurun, khususnya pada parameter rasa dan aroma. Kandungan zat gizipaling tinggi terdapat pada roti manis P3 dengan substitusi tepung spirulina sebesar 20\%.Roti manis yang paling disukai oleh konsumen adalah roti manis $\mathrm{P} 1$ dengan substitusi tepung spirulina sebesar $10 \%$ dengan penilaian netral.

\section{SARAN}

Roti manis P1 dengan substitusi tepung spirulina sebesar $10 \%$ merupakan roti manis terbaik dengan kandungan zat gizi (kecuali lemak) yangsesuai dengan anjuran komposisi makanan tambahan berdasarkan WHO dan tingkat kesukaannya paling tinggi dibandingkan dengan perlakuan lain.Pemberian isian pada roti manis, misal pasta cokelat,dapat meningkatkan kadar lemak, selain itu juga dapat meningkatkan tingkat kesukaan panelis terhadap roti manis. Peningkatan kadar lemak pada roti manis juga dapat dilakukan dengan memberikan olesan margarin pada permukaan roti manis. Pemberian perisa dalam pembuatan roti manis substitusi tepung spirulina dapat dilakukan untuk untuk menutupi aroma langu dari tepung spirulina.

\section{UCAPAN TERIMA KASIH}

Ucapan terima kasih disampaikan kepada Dinas Pendidikan Provinsi Jawa Tengah Kementerian Pendidikan dan Kebudayaan atas 
Hibah Penelitian Terapan Tahun 2013 dengan nomor 1139/UN7.5/P6/2013 tanggal 19 November 2013.

\section{DAFTAR PUSTAKA}

1. World Health Organization (WHO). Global Helath Risks Mortality and Burden of Disease Attributable to Selected Major Risk. Geneva : WHO. 2009.

2. Kementerian Perencanaan Pembangunan Nasional. Rencana Aksi Nasional Pangan dan Gizi 20112015;ISBN 978-979-3764-68-9. 2011.

3. Badan Penelitian dan Pengembangan Kesehatan. Riset Kesehatan Dasar (RISKESDAS) 2013. Jakarta : Kemenkes RI. 2013.

4. Katona P, Apte JK. The Interaction beetween Nutrition and Infection. Clinical Infectious Disease Society 2008;46:1582-8.

5. Holden C, Macdonald A. Nutrition and Child Health. London: Harcourt Publishers; 2000.

6. Kementerian Kesehatan Republik Indonesia. Profil Kesehatan Indonesia 2012. Jakarta : Kemenkes RI. 2013.

7. Ditjen Bina Gizi dan Kesehatan Ibu dan Anak. Perkembangan Masalah Gizi dan Penguatan Pelayanan Gizi dalam Pencegahan Stunting di Indonesia. Jakarta : Kemenkes RI. 2013.

8. Moersintowarti B. Narendra TSS, Soetjiningsih, Hariyono Suyitno, IG. N. Gde Ranuh, Sambas Wiradisuria. Tumbuh Kembang Anak dan Remaja: Ikatan Dokter Anak Indonesia. 2002.

9. Muller O, Krawinkel M. Malnutrition and Health in Developing Countries. CMAJ Aug 2, 2005; 173 (3).

10. Lynch SR. Interaction of Iron with Other Nutrients. Nutrition Reviews Vol. 55 No. 4.1997.

11. Ditjen Bina Gizi dan Kesehatan Ibu dan Anak. Panduan Penyelenggaraan Makanan Tambahan Bagi Balita Gizi Kurang. Jakarta : Kemenkes RI. 2011.

12. Golden MH. Proposed Recommended Nutrient Densities for Moderately Malnourished Children. Food and Nutrition Bulletin Vol. 30 No. 3 The United Nation University. 2009.

13. World Health Organization (WHO). Technical Note: Supplementary Foods for the Management of Moderate Acute Malnutrition in Infants and Children 6-59 months of age. Geneva, World Health Organization. 2012.

14. Hug C,von der Weid D. Spirulina in the Fight Against Malnutrition. Fondation Antenna Technologies. 2011.

15. Tabita A. Karakteristik Fungsional Protein Spirulina platensis. Skripsi. Semarang: Universitas Katholik Soegijapranata; 2012.

16. Sanchez M, et al. Spirulina (Arthrospira): An Edible Microorganism. Universidad Javeriana Bogota;2003.

17. Christwardana M dan Nur H. Spirulina platensis: Potensinya sebagai Bahan Pangan Fungsional. Jurnal Aplikasi Teknologi Pangan Vol. 2 No. 1. 2013
18. Falquet J. The Nutritional Aspects of Spirulina.ANTENNA Technologies. 1997.

19. Simpore J, et al. Nutrition Rehabilitation of Undernourished Children Utilizing Spiruline and Misola. Nutrition Journal. 2006; 5:3.

20. Andarwulan Nuri, Kusnandar Feri, Herawati Dian. Analisis Pangan. Jakarta: Dian Rakyat. 2011.

21. Association of Analytical Chemist (AOAC). Official Methodes of Analysis of the Association of Analytical Chemist. USA: Analysis of the Association of Analytical Chemist Publisher. 2005.

22. Dwi S, Anton A, Maya PS. Analisis sensori untuk industri pangan dan agro. Bogor: IPB Press. 2010.

23. Gallagher ML. The Nutrient and Their Metabolism. In: Mahan LK, Stump SE, editors. Krause's Food and the Nutrition Care Process 13th edition. Philadelphia: WB Saunders Company; 2012.

24. Muchtadi T dan Ayustaningwarno F. Teknologi Proses Pengolahan Pangan. Bandung: Alfabeta. 2010.

25. Yustianti L dan Hariyadi P. Kajian Formulasi dan Proses Pemanggangan Roti Manis Kaya Karotenoida dengan Substitusi Tepung Ubi Jalar (Ipomoea batatas L.) dan Minyak Sawit. Kumpulan Hasil Penelitian Terbaik Bogasari Nugraha 19982001. 1999.

26. Navacchi MFP, et al. Development of Cassava Cake Enriched with its Own Bran and Spirulina platensis. Acta Scientarium Technology Maringa vol. 34, n. 4. 2012

27. Maria S. Penentuan Kadar Logam Besi (Fe) dalam Tepung Gandum dengan cara Dekstruksi Basah dan Kering dengan Spektrofotometri Serapan Atom Sesuai SNI 01-3751-2006. Skripsi. Departemen Kimia Fakultas MIPA USU Medan. 2009.

28. Food Safety and Standards Authority of India (FSSAI). Trainning Manual for Food Safety Regulators. New Delhi : Food Safety and Standards Authority of India. Vol I. Introduction to Foof and Food Processing. 2010.

29. Habib MAB dan Parvin M. A Review on Culture, Production and Us.e of Spirulina as Food for Humans and Feeds for Domestic Animals and Fish. Food and Agriculture Organization (FAO) FIMA/C1034. 2008.

30. Michaelsen KF, et al. Choices of Foods and Ingredients for Moderately Malnourished Children 6 months to 5 years of age. Food and Nutrition Bulletin Vol. 30 No. 3 The United Nation University. 2009. 